\title{
Criteria on Sanitary Landfill Suitability Analysis in the Ifugao Province, Philippines
}

\author{
Mark Joseph J. Buncag, Ph.D \\ Faculty, Palawan State University, Palawan, Philippines
}

\begin{abstract}
The Philippines is facing an alarming contemporary environment issue on solid wastes generation, which primarily caused by the increase of population, improvement of living standards, rapid economic growth, and industrialization, especially in urban areas. The establishment of a sanitary landfill is highly needed as a mechanism to manage generated solid wastes. However, it requires thorough suitability analysis to foresee and prevent irreversible adverse impacts on society and the ecological environment. This study determined criteria and sub-criterion in the suitability analysis on the establishment of a sanitary landfill in Ifugao Province. This study utilized secondary analysis GIS analysis of required maps based on landfill siting area requirement using ArcMap GIS software licensed to UPLB. Results show that criteria in the suitability analysis classified into economic, environmental, and physical criteria as well as the identified policy consideration, exclusionary zones, and sub-criterion zones. The implementation of suitability analysis through GIS analysis is highly recommended.
\end{abstract}

Keywords: Criteria and Suitability Analysis

\section{Introduction}

The Philippines is currently encountering alarming environmental issues, particularly on the generation of solid wastes in which the trend is increasing that caused by the increase of population, improvement of living standards, rapid economic growth, and industrialization especially in urban and dense areas (Senate Economic Planning Office, 2017). In 2012, the computed solid waste generation in the country is $37,427.46$ tons per day and steadily increase until 2016, with 40,087.45 tons per day (NSWMC, 2015). Most of the generated solid wastes were from residential (57\%) then commercial (27\%) followed by institutional $(12 \%)$ and industrial $(4 \%)$ (NSWMC, 2017).

The formulated mechanism of the national government is mainly stated in RA 9003, otherwise known as the Ecological Solid Wastes Management Act of 2001, in which the establishment of sanitary landfills by the local government units (LGU) is required. In the country, there 86 existing sanitary landfills that cater the increasing generated solid wastes and these existing sanitary landfills has its own capacity (NSWMC, 2015). In this case, the organization of sanitary landfills and growth or development of existing sanitary landfills in local government units is needed and mandate in RA 9003 to run the solid wastes generate by dissimilar sources correctly.

The absence of proper wastes management may cause human health problems such as diarrhea, helminthiasis, typhoid/paratyphoid, cholera and hepatitis A that may cause complications and death. In addition, flora and fauna in both terrestrial and aquatic ecosystems can be negatively affected by mismanaged wastes. These diseases can be mitigated through waste management like the establishment of a sanitary landfill.

The establishment of a sanitary landfill is one of the strategies to manage solid wastes to mitigate health-related problems and impacts on wildlife and marine organism. However, there are some criteria in identifying suitable sites for the establishment of sanitary landfill based on the guidelines of DENR through DAO 1998-50. These criteria include land use, road, slope, river, groundwater, key biodiversity/protected areas, land cover, groundwater, soil, erosion susceptibility, cultural sites, settlements/built-upareas and faults.

Ifugao is one of the provinces in the Cordillera Administrative Region (CAR) and can be found in a mountainous area. This province needs a sanitary landfill that will cater to the wastes generated by households, tourists and other institutions in the entire province. So, this study determined criteria in the suitability analysis of the establishment of the sanitary landfill. 


\section{Research Method Study Area}

This study mainly focused on the province of Ifugao, Philippines, in determining the suitable sanitary landfill sites covering its all municipalities. It has 11 municipalities and 175 barangays. Ifugao is situated at the foot of the Cordillera Mountain range. It is surrounded on the west by Benguet, on the south by Nueva Vizcaya, on the east by Isabela and on the north by Mt. region. It is generally located at 1650 '0' ' $\mathrm{N}$ and $12110^{\prime} 0$ E. It has a land area total of 2,517.78 sq. Km. spread over its 11 municipalities. The biggest municipality in terms of the land area is Aguinaldo, with $454.51 \mathrm{sq}$. $\mathrm{Km}$. or $18.05 \%$ of the total local land area, while the smallest number of is Hingyon with 114.56 sq. $\mathrm{km}$. or $4.55 \%$.

The research area showed in figure 1. This covered all municipalities of Ifugao province.

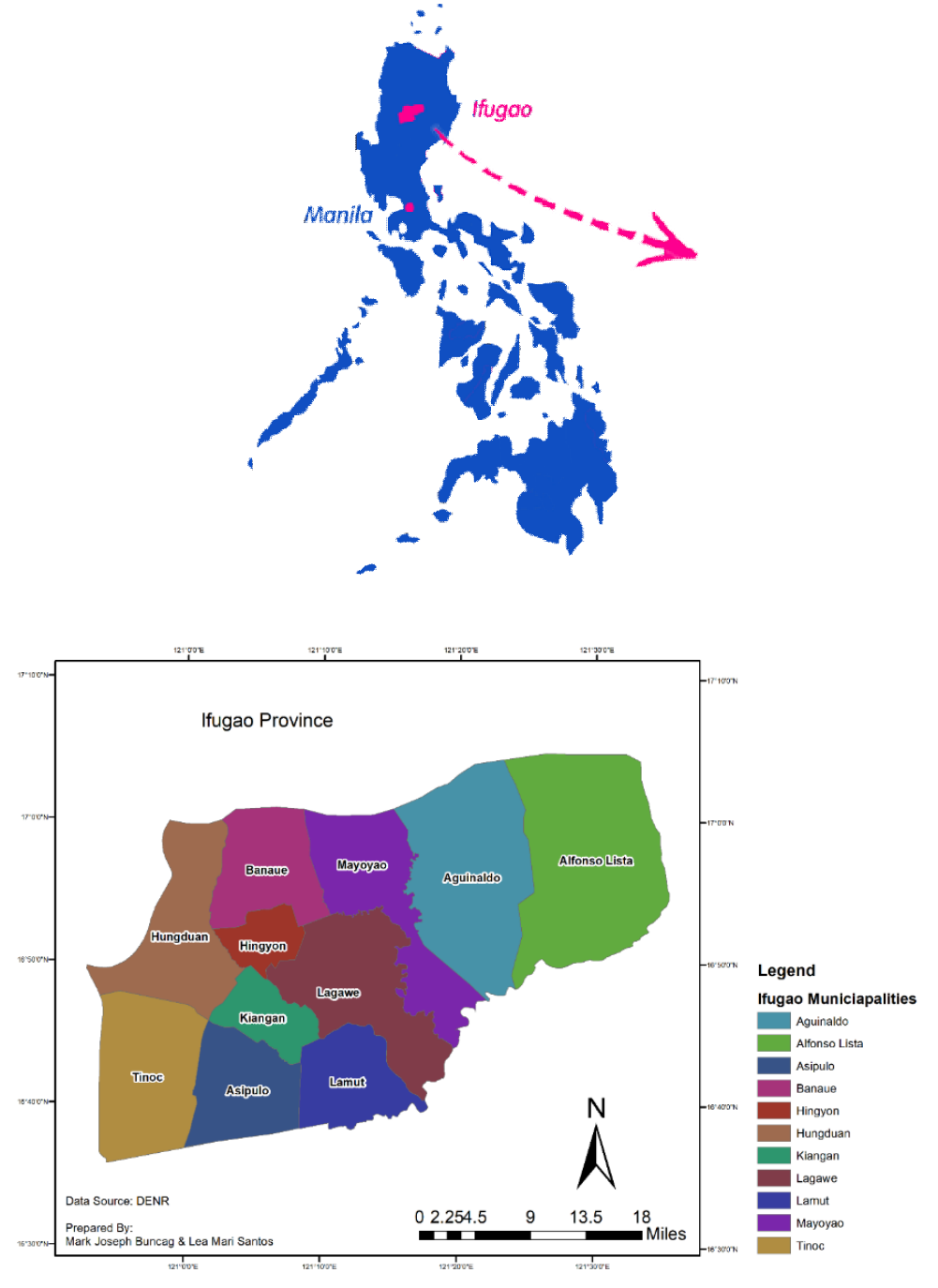

Figure 1. Provincial Map of Ifugao

In this study, guidelines from the Department of Environment and Natural Resources (DENR) and Housing and Land Use Regulatory Board (HLURB) was utilized as criteria for landfill site selection. 
Available secondary data in shapefile format requested from DENR was utilized in this study for spatial analysis. DEM data was downloaded from the USGS Earth Explorer portal to generate a slope map of the study area. This study utilized GIS analysis to assess each criterion under economic, physical, and environmental criteria.

\section{Results and Discussions}

Minimum Dataset Requirements

Table 1. List of all the Data Requirements for Landfill Suitability Mapping

\begin{tabular}{|c|c|c|}
\hline Criteria & Dataset Requirement* & Feature class \\
\hline \multicolumn{3}{|l|}{ Economic } \\
\hline Land use & "Existing land use & "Polygon" \\
\hline Distance from roads & Road Network & Line \\
\hline Slope & $\begin{array}{l}\text { ASTER DEM (30m resolution) } \\
\text { (source: USGS Earth Explorer) }\end{array}$ & Polygon \\
\hline \multicolumn{3}{|l|}{ Environmental } \\
\hline $\begin{array}{l}\text { Distance from surface } \\
\text { waters/rivers }\end{array}$ & Surface water/River Network & Line \\
\hline Groundwaters & Groundwater map & Polygon \\
\hline $\begin{array}{l}\text { Distance from Key } \\
\text { Biodiversity /Protected Areas }\end{array}$ & Biodiversity /Protected Areas Map & Polygon \\
\hline Land Cover & Land cover map & Polygon \\
\hline Soil Erosion & Erosion Map & Polygon \\
\hline Soil permeability & Soil map & Polygon \\
\hline \multicolumn{3}{|l|}{ Physical } \\
\hline $\begin{array}{l}\text { Distance from Built-up areas/ } \\
\text { settlements }\end{array}$ & Built-up/settlement sites & 'Polygon \\
\hline $\begin{array}{l}\text { Distance from cultural } \\
\text { heritage }\end{array}$ & POIs of cultural sites & Points \\
\hline $\begin{array}{l}\text { Distance to Faults } \\
\text { (Seismic Conditions) }\end{array}$ & Active Faults & Line \\
\hline
\end{tabular}

*Data Source: DENR, except Slope map- generated from DEM data downloaded from USGS Earth Explorer portal 
Table 2. Identified Landfill Site Selection Criteria with Policies/Considerations, Exclusionary Zones and Sub-criterion Zones

\begin{tabular}{|c|c|c|c|}
\hline Criteria & Policies / Considerations & Exclusionary Zones & Sub-criterion zones \\
\hline \multicolumn{4}{|l|}{ Economic } \\
\hline Land Use & $\begin{array}{l}\text { The site shall avoid converting land witl } \\
\text { high productivity }\end{array}$ & $\begin{array}{l}\text { Built-up areas, Closed } \\
\text { canopy, mature trees } \\
\text { covering }>50 \text { percent, } \\
\text { Open canopy, mature } \\
\text { trees covering }<50 \\
\text { percent, Mangrove } \\
\text { vegetation, Pine forest, } \\
\text { Mossy Forest, lake, } \\
\text { marshy area and } \\
\text { swamp, and riverbeds }\end{array}$ & $\begin{array}{l}\text { Quarry/other plantations; } \\
\text { Grassland, grass covering } \\
>70 \text { percent; Cultivated } \\
\text { area mixed with } \\
\text { brushland/ grassland; } \\
\text { Arable land; Crops mainly } \\
\text { cereals and sugar; } \\
\text { Cropland mixed with } \\
\text { coconut/other } \\
\text { plantation/open canopy }\end{array}$ \\
\hline $\begin{array}{l}\text { Distance from } \\
\text { roads }\end{array}$ & $\begin{array}{l}\text { The site shall be accessible from major } \\
\text { roadways and thoroughfares provided } \\
\text { that if it is not accessible, the project } \\
\text { design shall include means of access. }\end{array}$ & $100 \mathrm{~m}$ from main roads & $\begin{array}{l}101-250 \mathrm{~m} \\
251-500 \mathrm{~m} \\
501-750 \mathrm{~m} \\
>750 \mathrm{~m}\end{array}$ \\
\hline Slope & $\begin{array}{l}\text { Ideally, the site has a gently sloped } \\
\text { topography. Areas with above } 20 \% \\
\text { slope should be avoided. }\end{array}$ & $\begin{array}{l}\text { Avoid hilly area with } \\
\text { ground slopes } \\
\text { nominally greater than } \\
20 \% \text { (DAO 98-50). As } \\
\text { consideration for hilly } \\
\text { areas, landfilling in } \\
\text { hilly areas is feasible } \\
\text { but with an increase in } \\
\text { cost associated with } \\
\text { engineering and access } \\
\text { arrangement. }\end{array}$ & $\begin{array}{l}0-18 \% \\
18-35 \% \\
35-55 \% \\
55-65 \% \\
>65 \%\end{array}$ \\
\hline
\end{tabular}

\begin{tabular}{|c|c|c|}
\hline \multicolumn{3}{|l|}{ Environmental } \\
\hline $\begin{array}{l}\text { Distance from } \\
\text { surface waters }\end{array}$ & $\begin{array}{l}\text { The site shall not be located within } 300 \quad 300-\mathrm{m} \text { from surface } \\
\text { meters of watershed areas or upgradient waters (DAO 98-50) } \\
\text { (point of intake) of any surface waters } \\
\text { used for public or private drinking water } \\
\text { supply irrigation or livestock. }\end{array}$ & $\begin{array}{l}301-1000 \mathrm{~m} \\
1001-1500 \mathrm{~m} \\
1501-2000 \mathrm{~m} \\
2001-2500 \mathrm{~m} \\
>2500 \mathrm{~m}\end{array}$ \\
\hline Groundwaters & $\begin{array}{l}\text { Avoid areas within significant } \\
\text { groundwater reservoir or water supply } \\
\text { intakes used for private or public } \\
\text { drinking irrigation or livestock shall also } \\
\text { be excluded. }\end{array}$ & $\begin{array}{l}\text { Impermeable Rocks } \\
\text { Generally without } \\
\text { Significant Groundwater; } \\
\text { Dominantly through } \\
\text { Fracture and Solution } \\
\text { Opening Flow; } \\
\text { Dominantly Intergranular } \\
\text { Flow }\end{array}$ \\
\hline
\end{tabular}


Distance from environmentally sensitive areas

(Distance from

Key Biodiversity

/Protected Areas)

Land cover
The site shall not be located within $500 \quad 500 \mathrm{~m}$ from meters of the boundaries of ecologically environmentally sensitive areas proclaimed as protected sensitive areas (DAO areas under the National Integrated 98-50) Protected Areas System (NIPAS) Act, or by any related issuances.
$501-1000 \mathrm{~m}$

1001-1500 m

$1501-2000 \mathrm{~m}$

$>2000 \mathrm{~m}$
Avoid areas with closed forest and natural marshland.
Built-up areas, natural Natural barren/grassland; marshland, closed forest

Cultivated annual/perennial; Wooded land: Fallow, shrubs and wooded grass/forest plantation; Open forest, broadleaved; Open forest, coniferous

$\begin{array}{llll}\begin{array}{l}\text { Soil erosion } \\ \text { Susceptibility }\end{array} & \begin{array}{l}\text { Avoid locating site in areas that may be } \\ \text { subject to inundation during highly } \\ \text { severe erosion }\end{array} & \begin{array}{l}\text { Areas with highly } \\ \text { severe susceptibility } \\ \text { (DAO 98-50) }\end{array} & \begin{array}{l}\text { No Apparent } \\ \text { Erosion/Unclassified } \\ \text { Erosion; Slight Erosion; } \\ \text { Moderate Erosion; Severe }\end{array} \\ & & & \text { Erosion; River/Reservoir } \\ \text { Soil permeability } & \begin{array}{l}\text { The site shall not be located in unstable, Areas with highly } \\ \text { very soft and settling soils (sand, coarse permeable soils (DAO }\end{array} & \text { Clay (loam, clay); } \\ & \begin{array}{ll}\text { sand ountain soil; Rock land; } \\ \text { liquefaction and slumping. }\end{array} & \begin{array}{l}\text { Silt (silty clay, silty loam)/ } \\ \text { complex; Loam }\end{array}\end{array}$

\section{Physical}

\begin{tabular}{|c|c|c|c|}
\hline $\begin{array}{l}\text { Distance from } \\
\text { settlements }\end{array}$ & $\begin{array}{l}\text { The sites shall not be located in or } \\
\text { within } 250 \text { meters of existing or } \\
\text { proposed residential, commercial or } \\
\text { urban development areas among other } \\
\text { land use classes }\end{array}$ & $\begin{array}{l}250 \mathrm{~m} \text { from } \\
\text { settlements (DAO } \\
98-50)\end{array}$ & $\begin{array}{l}251-1000 \mathrm{~m} \\
1001-1500 \mathrm{~m} \\
1501-2000 \mathrm{~m} \\
2001-2500 \mathrm{~m} \\
>2500 \mathrm{~m}\end{array}$ \\
\hline $\begin{array}{l}\text { Distance from } \\
\text { cultural heritage }\end{array}$ & $\begin{array}{l}\text { The sites shall not be located in or } \\
\text { within } 1000 \text { meters of areas with } \\
\text { historical, archaeological, cultural } \\
\text { geological, or scientific interests that are } \\
\text { more than } 100 \text { years old and declared by } \\
\text { traditional Commission for Culture and } \\
\text { the Arts National Historical Institute or } \\
\text { National Museum. }\end{array}$ & $\begin{array}{l}1000 \mathrm{~m} \text { from cultural } \\
\text { heritage sites (DAO } \\
98-50)\end{array}$ & $\begin{array}{l}1001-1500 \mathrm{~m} \\
1501-2000 \mathrm{~m} \\
2001-2500 \mathrm{~m} \\
2501-3000 \mathrm{~m} \\
>3000 \mathrm{~m}\end{array}$ \\
\hline $\begin{array}{l}\text { Distance to Faults } \\
\text { (Seismic } \\
\text { Conditions) }\end{array}$ & $\begin{array}{l}\text { Avoid areas within } 500 \text { meters of active } \\
\text { faults or in areas with an average return } \\
\text { period between } 50 \text { to } 100 \text { years for an } \\
\text { earthquake of magnitude } 6 \text { and above }\end{array}$ & $\begin{array}{l}500 \text { m from active } \\
\text { faults (World Bank } \\
\text { Guidelines), (DAO 98- } \\
50 \text { ) }\end{array}$ & $\begin{array}{l}501-1500 \mathrm{~m} \\
1501-2500 \mathrm{~m} \\
2501-3500 \mathrm{~m} \\
>3500 \mathrm{~m}\end{array}$ \\
\hline
\end{tabular}




\section{Polygon to Raster Output Maps}

The following maps are output maps after converting vector to raster data. These maps/layer will be input to spatial overlay analysis.

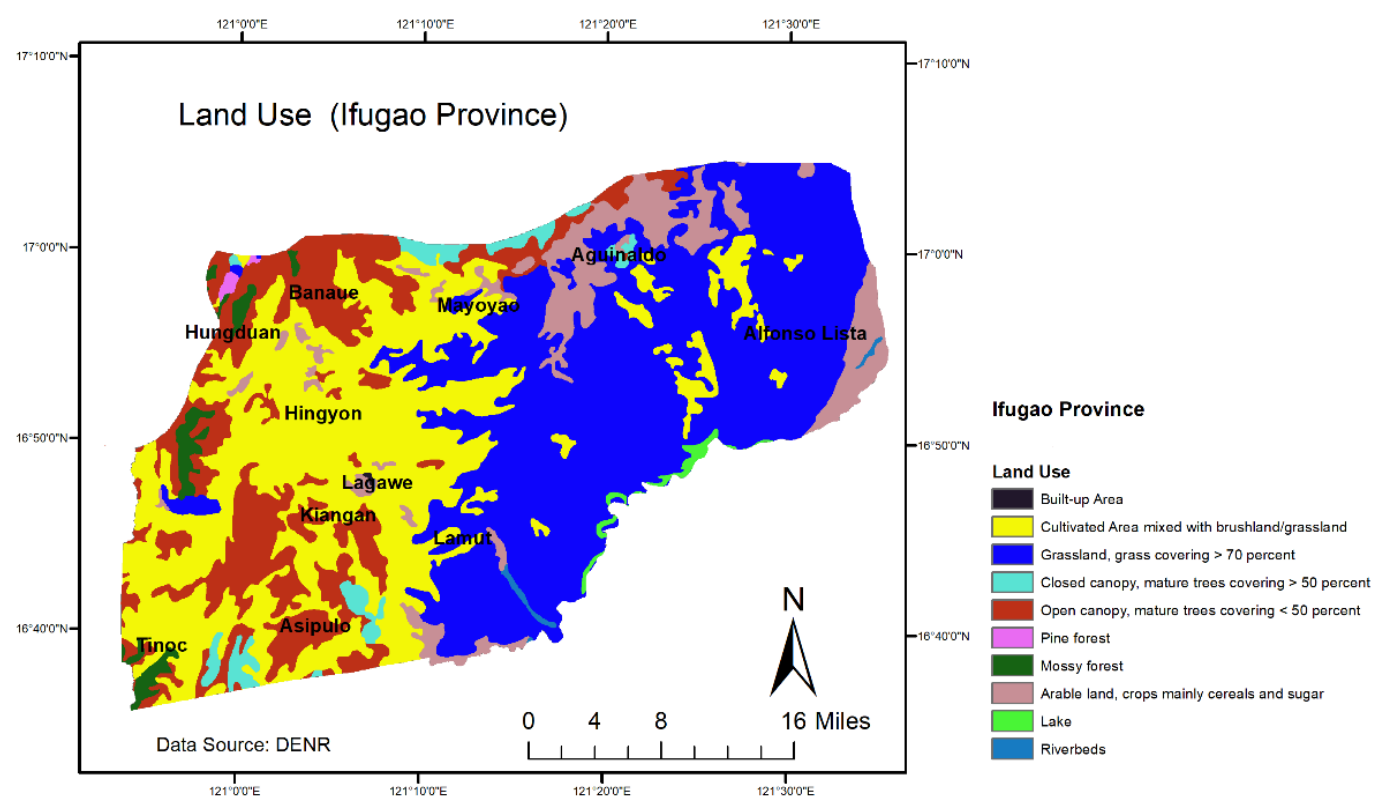

Figure 2. Land use map of Ifugao

Figure 2 shows the land use map of Ifugao. Land use is under the criterion Economic and comprises a weight of $54 \%$. The majority of the area appears to be grassland and cultivated areas in terms of land use.

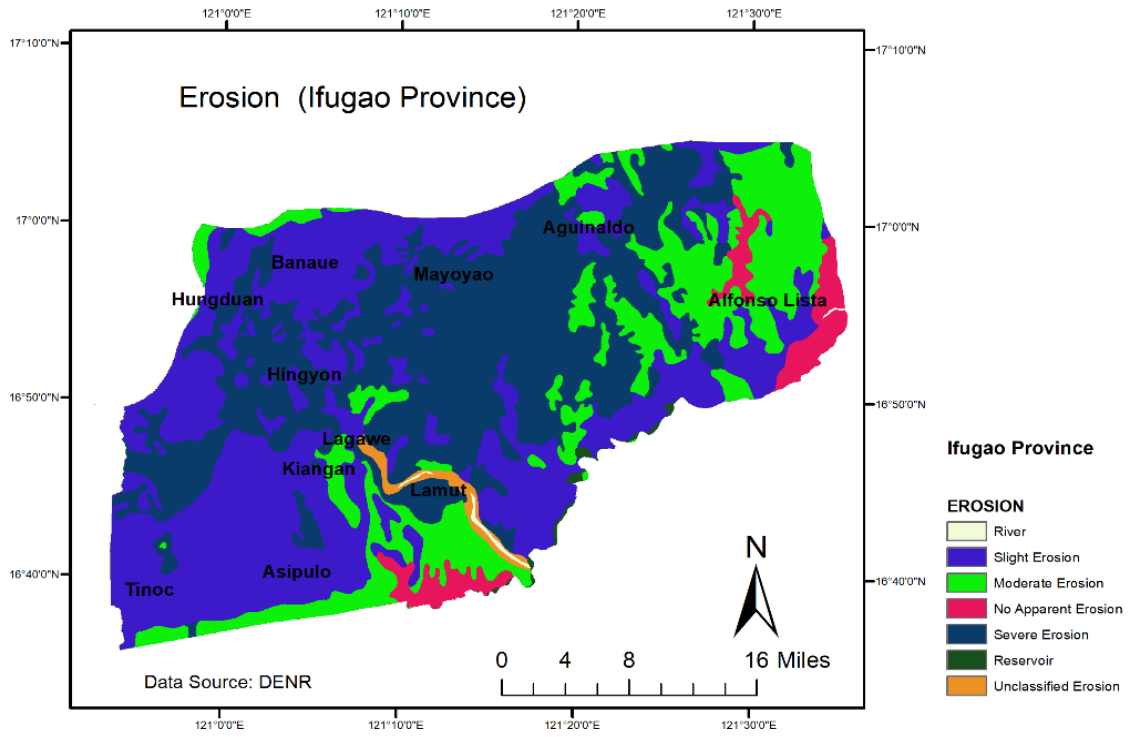

Figure 3. Erosion susceptibility map of Ifugao

Figure 3 shows the erosion susceptibility map of Ifugao. Erosion susceptibility is under the criterion Environmental, which comprises a weight of $12 \%$. The majority of the area appears to be susceptible to slight 
erosion. The municipality of Mayayao and some parts of Aguinaldo located at the center of Ifugao appears to be susceptible to severe erosion.

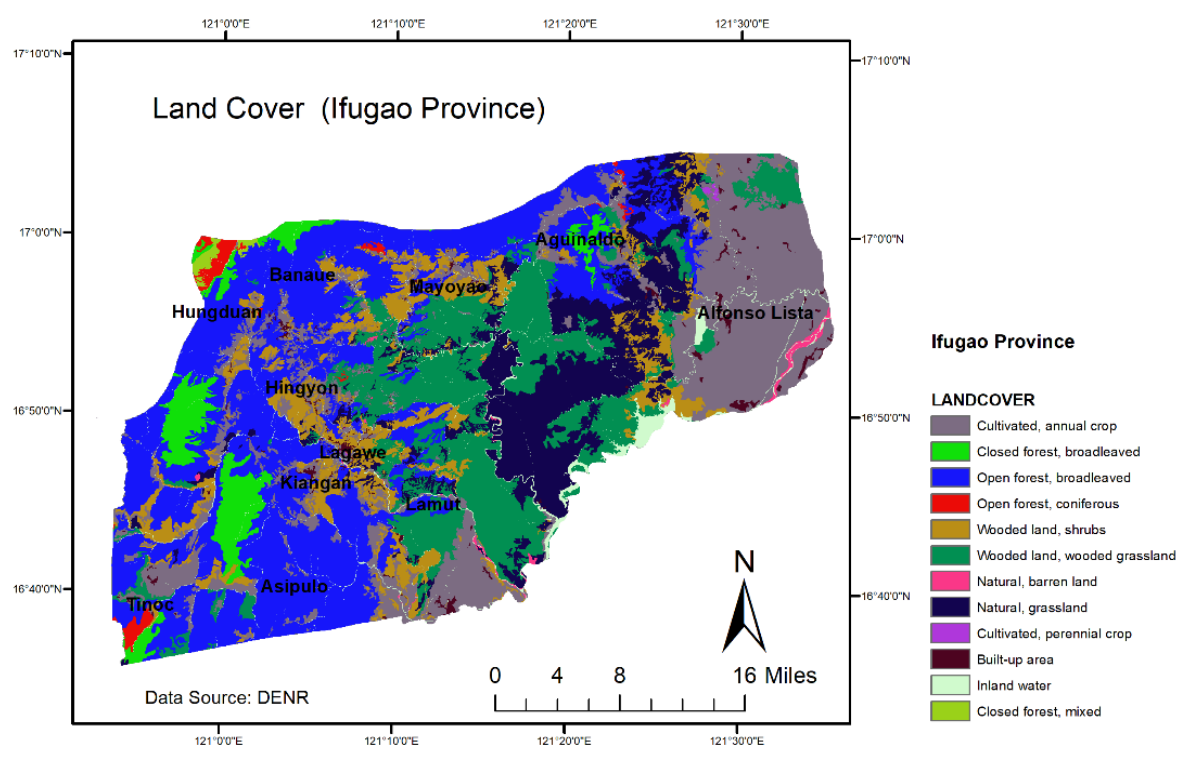

Figure 4. Land cover map of Ifugao

Figure 4 shows the land cover map of Ifugao. Land cover is under the criterion Environmental and comprises a weight of 5\%. The majority of the area appears to be an open forest with broadleaved trees and is located at the eastern part of the province. The center part is mostly wooded land, and the southwestern part is built-up areas. The western part of the province is cultivated areas with annual crops.

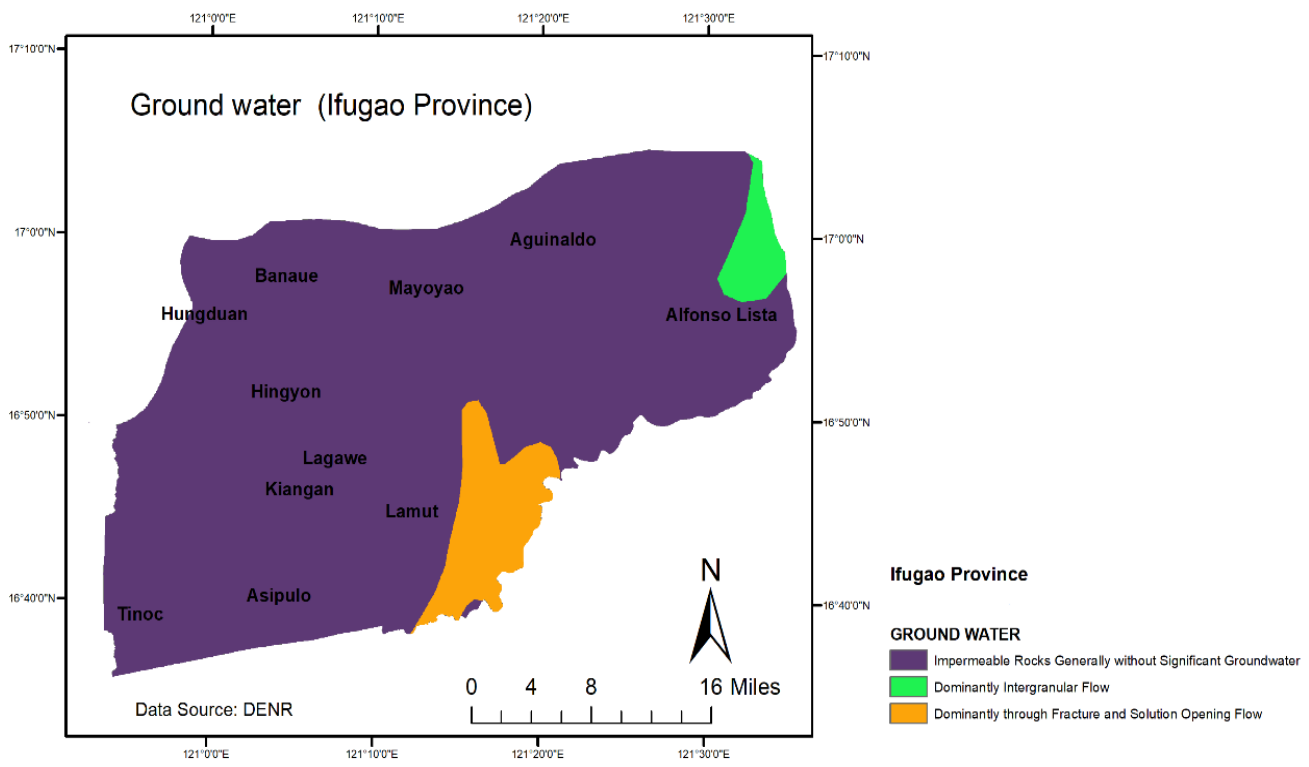

Figure 5. Groundwater map of Ifugao

Figure 5 shows the groundwater map of Ifugao. Distance from groundwater is under the criterion Environmental and comprises a weight of $31 \%$. The majority of the area appears to be impermeable rocks without significant groundwater. 


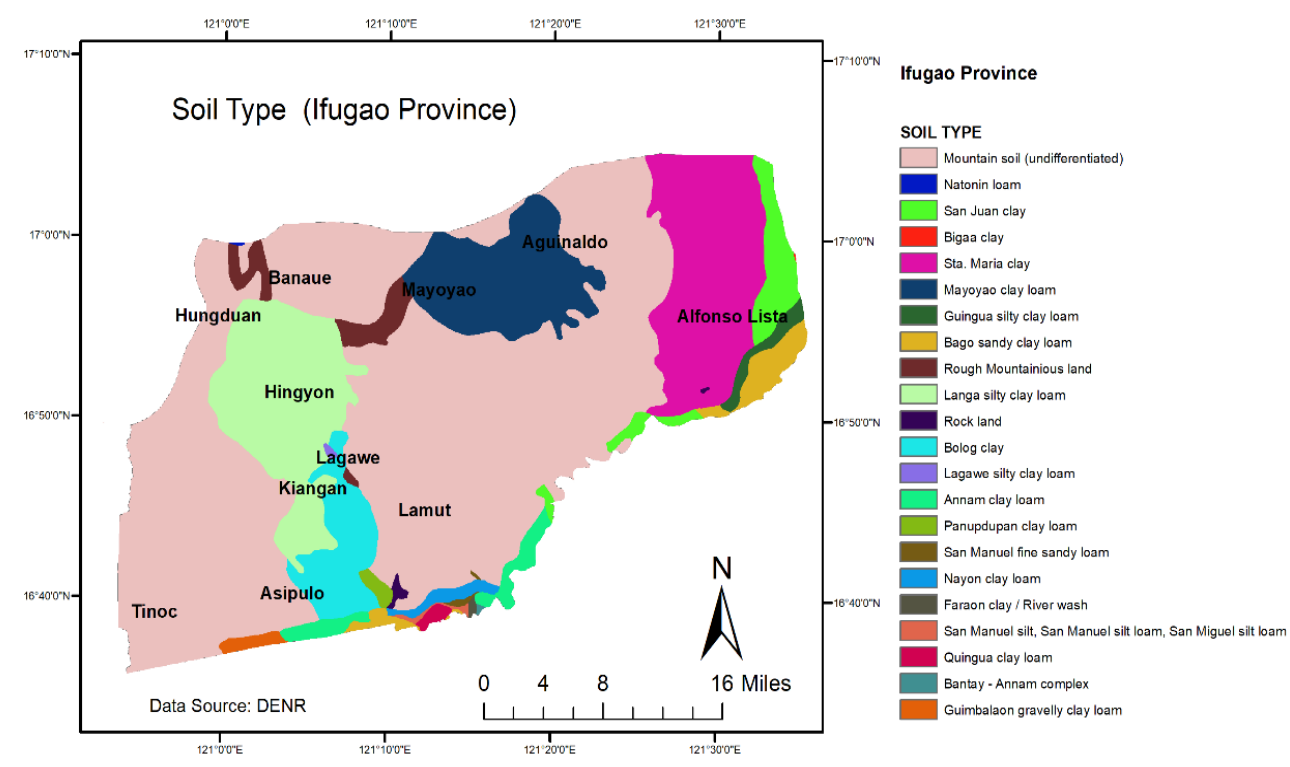

Figure 6. Soil type map of Ifugao

Figure 6 shows the soil type map of Ifugao. Soil type is under the criterion Environmental and comprises a weight of $16 \%$. Since Ifugao is a mountainous region, the majority of the soil type is undifferentiated mountain soil. Looking at the municipal level, Alfonso Lista, Mayaoyao, and Hingyon are represented by clay soil.

\section{Euclidean}

The figures below show the result maps after executing Euclidean Distance the following layers: distance from the road, distance from surface waters/rivers, distance from environmentally sensitive areas, distance from settlements, distance from cultural sites, and distance from faults. These showed the created zones and calculated Euclidean distance to the closest source. This zone represents the degree of influence of a specific criterion in a particular zone or distance from center to the determination of sanitary landfill site. 

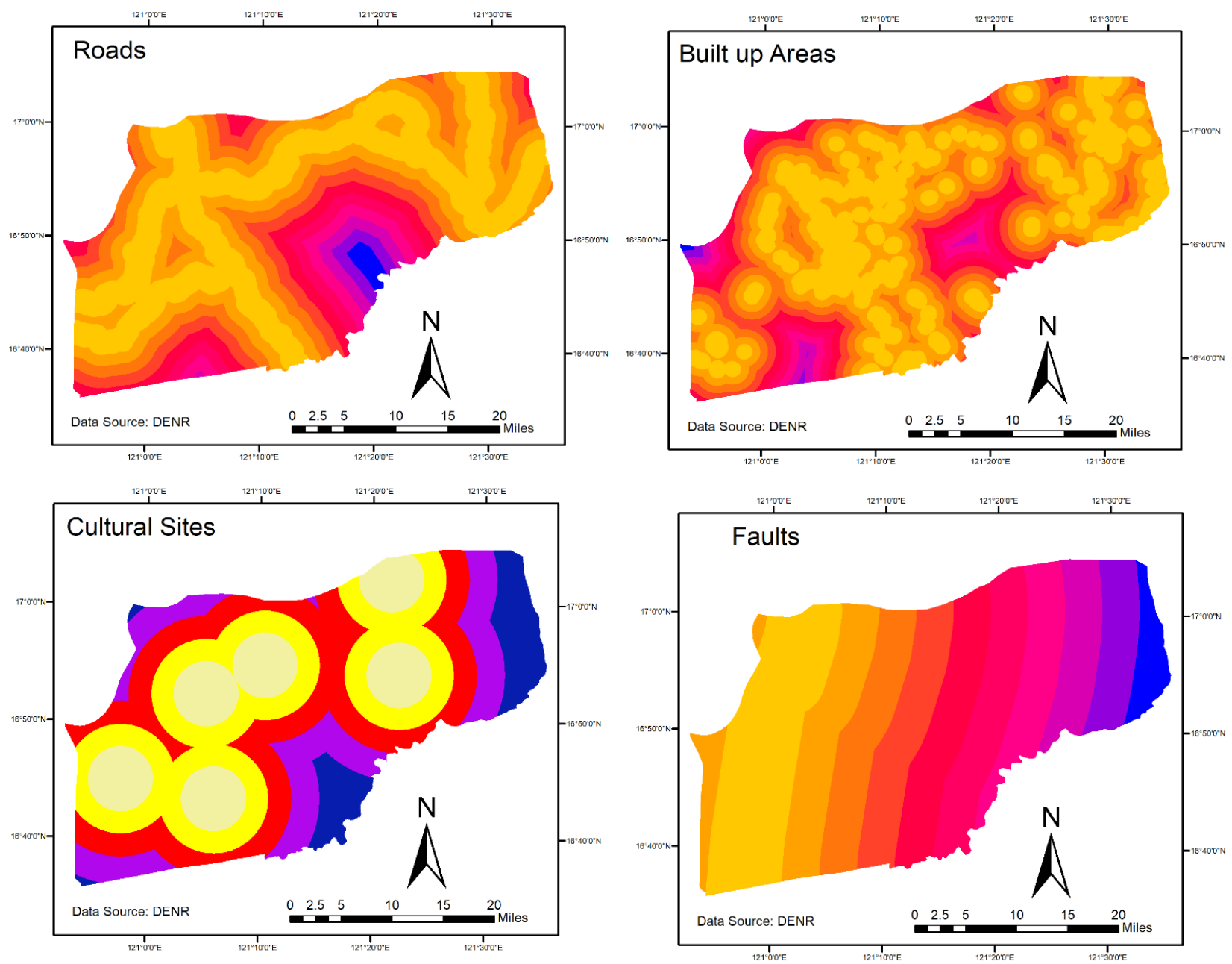

Figure 7. Result maps of Euclidian distance
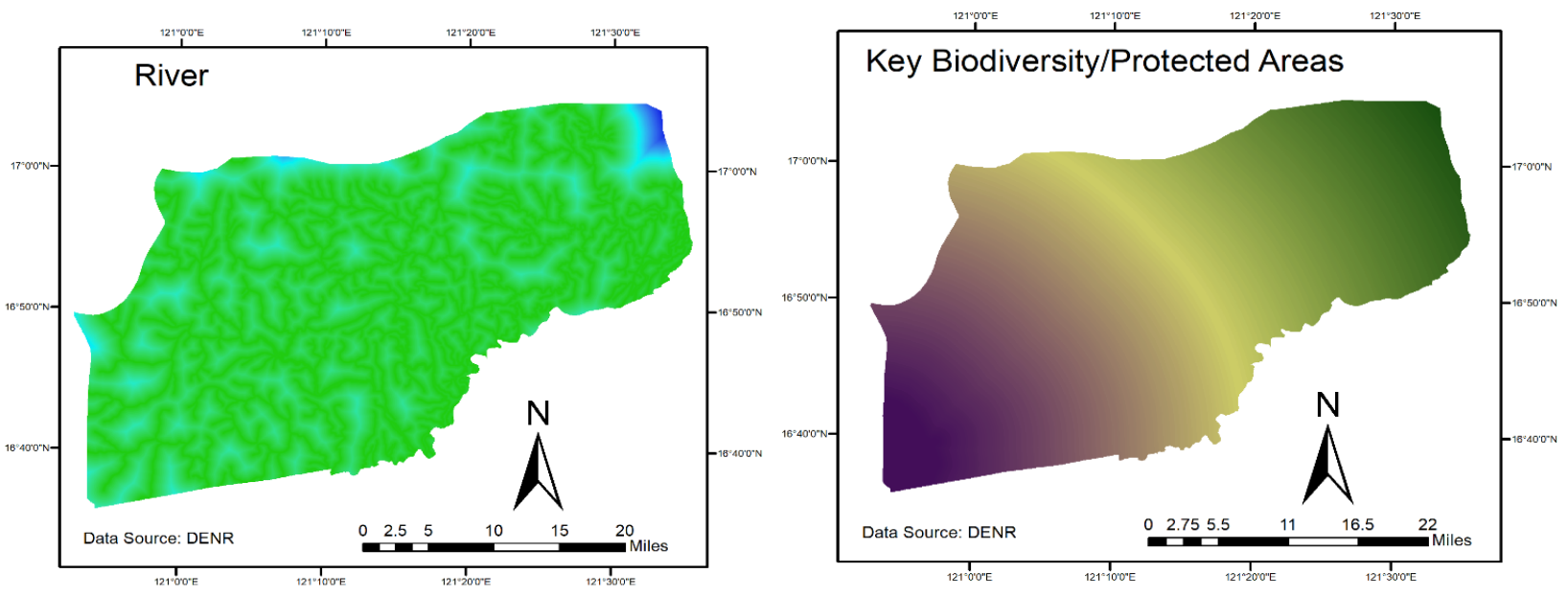


\section{Reclassification}

The figures below show the result maps after executing Reclassification the following layers: distance from the road, distance from surface waters/rivers, distance from environmentally sensitive areas, distance from settlements, distance from cultural sites, distance from faults and slope. These maps showed the reclassified zones created in Euclidean distance analysis based on the sub-criterion zones provided by both literatures and laws. These were reclassified into: restricted, very low suitability, low suitability, moderate suitability, high suitability and very high suitability.

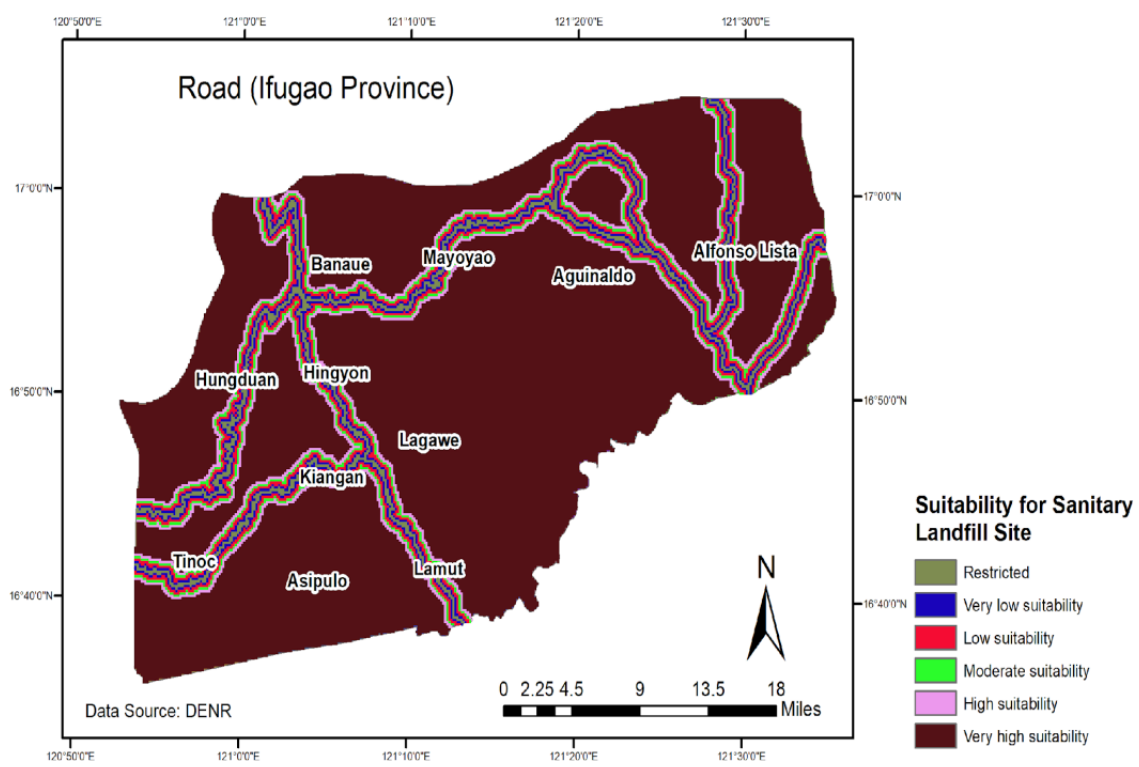

Figure 8. Output map for road network

Figure 8 shows the resulting map of road layer after executing reclassification. Road layer is under the criterion of Economic and comprises a weight of $30 \%$. Based on the map, the majority of the areas in Ifugao province fall on very high suitability for sanitary landfill site using a road layer.

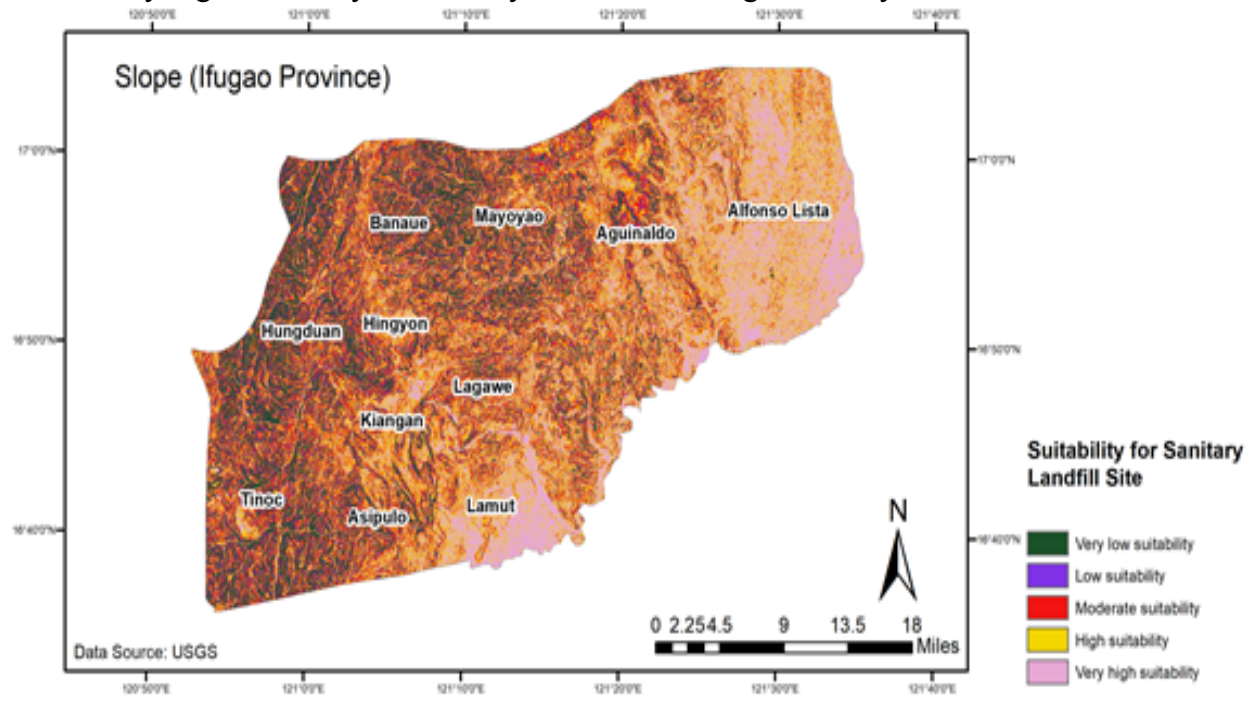

Figure 9. Output map for slope layer 
Figure 9 shows the resulting map of the slope layer after executing reclassification. The slope layer is under the criterion of Economic and comprises a weight of $16 \%$. Based on the map, large areas of Alfonso and Lamot fall on very high suitability, but the majority of the areas in Ifugao province fall on moderate to low suitability for sanitary landfill site using a slope layer.

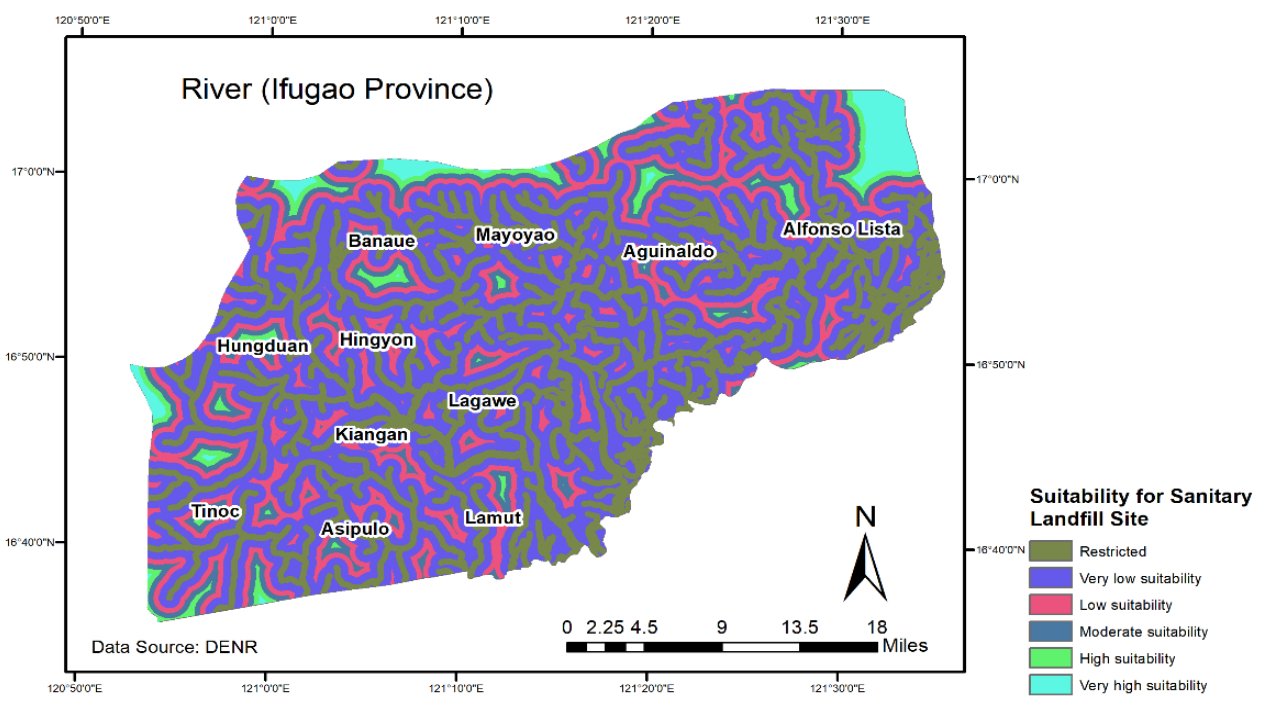

Figure 10. Output map for river network layer

Figure 10 shows the resulting map of river layer after executing reclassification. The river layer is under the criterion of Environment and comprises a weight of $31 \%$. Based on the map, Alfonso has the largest area that falls on very high suitability but the majority of the areas in Ifugao province fall on from low to restricted in terms of suitability for sanitary landfill site using a river layer.

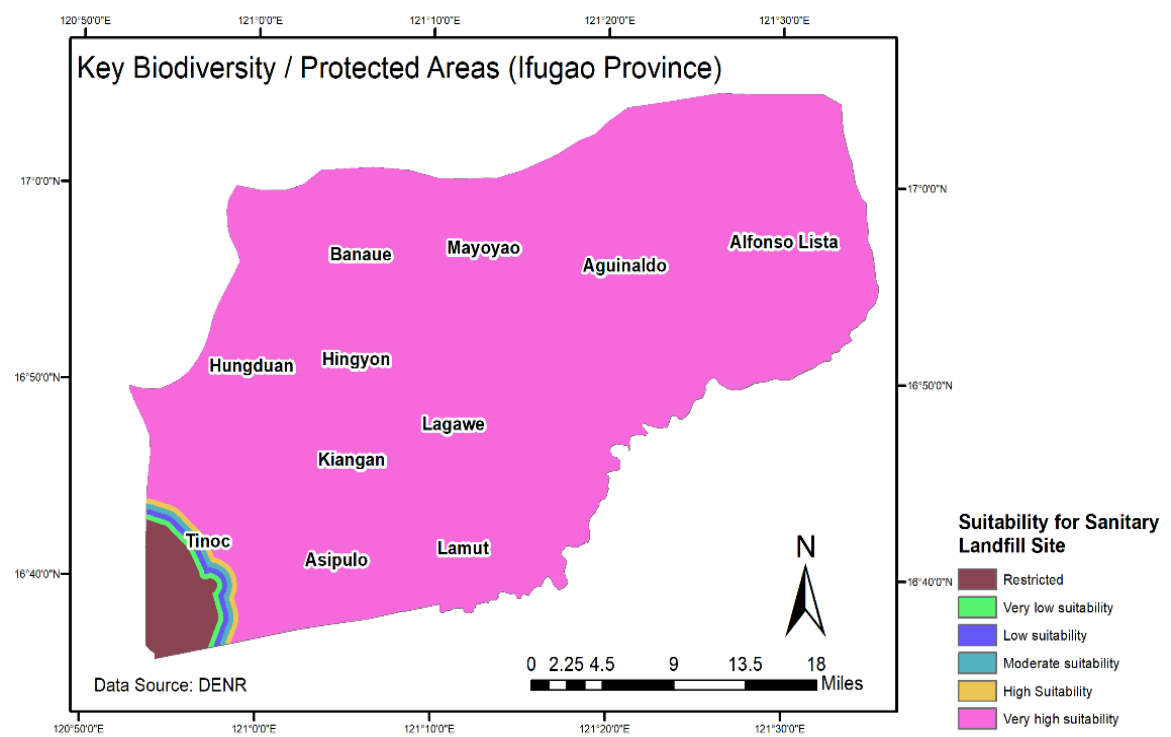

Figure 11. Output map for KBA layer

Figure 11 shows the resulting map of key biodiversity/protected areas layer after executing reclassification. Key biodiversity/protected areas layer is under the criterion of Environment and comprises a weight of $5 \%$. Based on the map, majority of the areas in Ifugao province fall on very high suitability for sanitary landfill sites using a key biodiversity/protected area layer. 


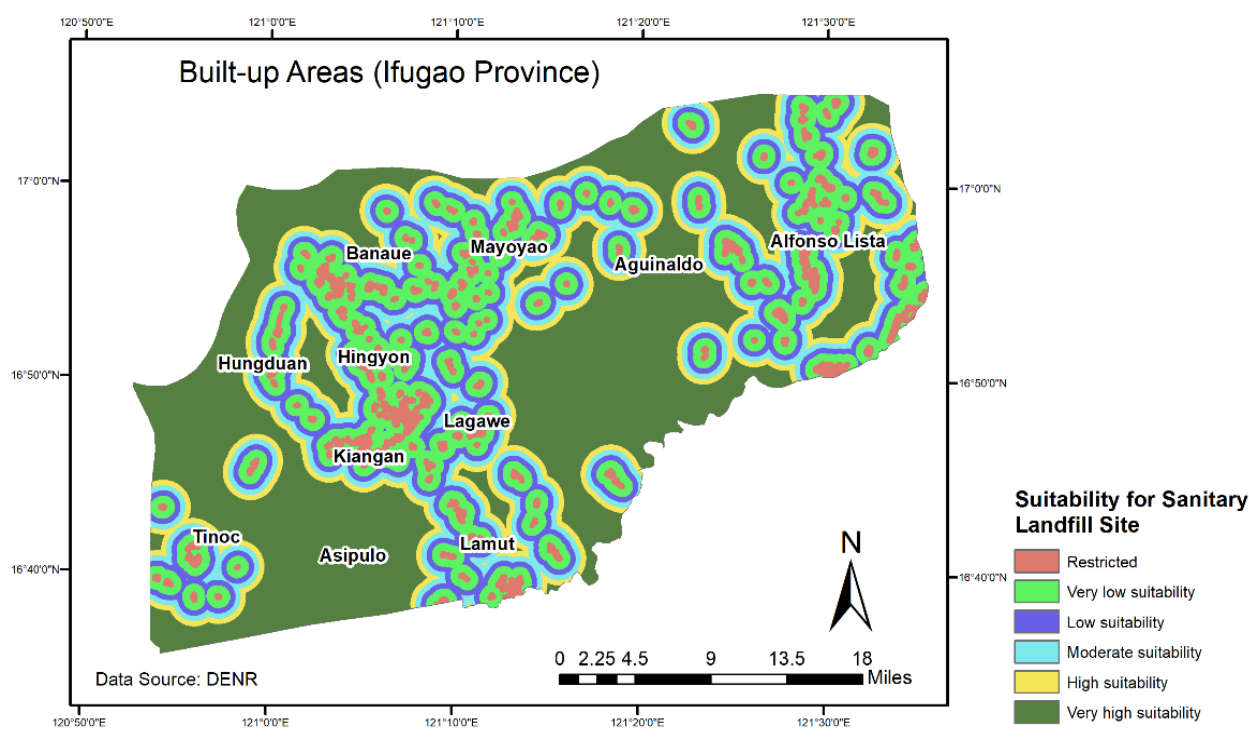

Figure 12. Output map for built-up area layer

Figure 12 shows the resulting map of the built-up layer after executing reclassification. The built-up layer is under the criterion of Physical and comprises a weight of $68 \%$. Based on the map, large areas in Ifugao province fall on very high suitability for sanitary landfill site using a built-up layer. Still, there are large areas that fall on moderate to very low suitability in most of its municipalities.

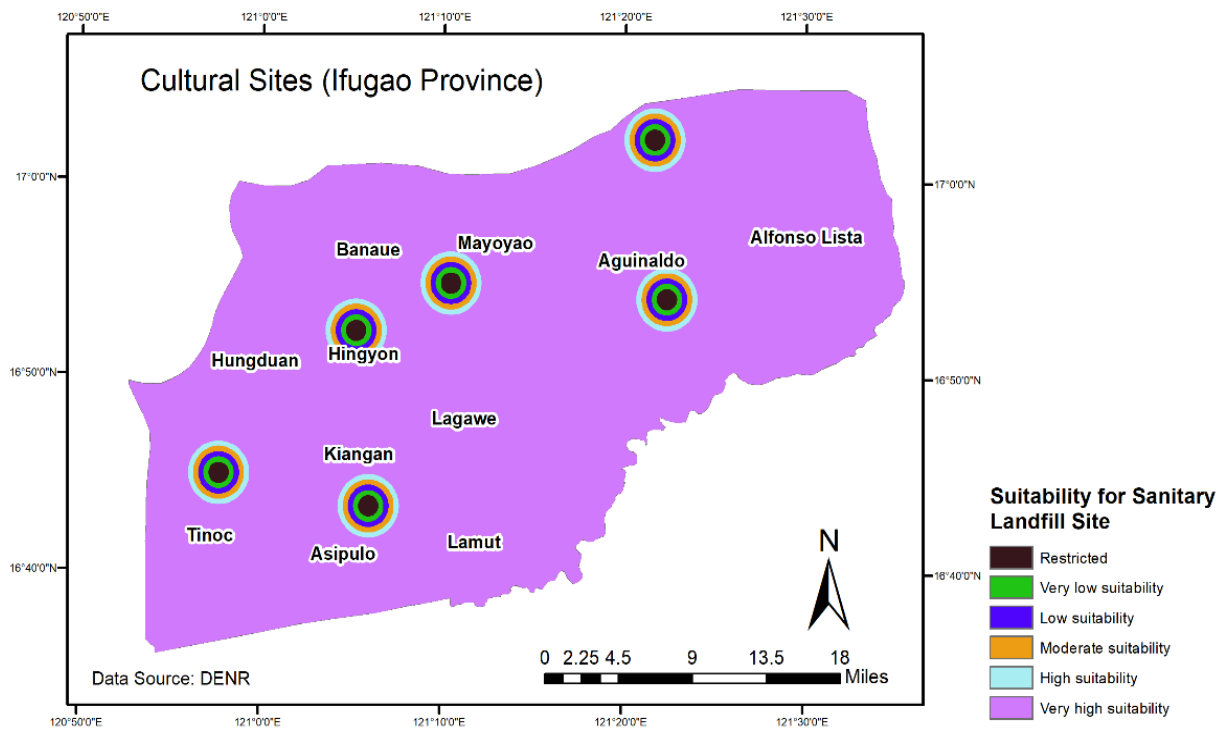

Figure 13. Output map for cultural site layer

Figure 13 shows the resulting map of the cultural sites layer after executing reclassification. The cultural sites layer is under the criterion of Physical and comprises a weight of $22 \%$. Based on the map, a large area in Ifugao province fall on very high suitability for sanitary landfill site using a cultural sites layer. 


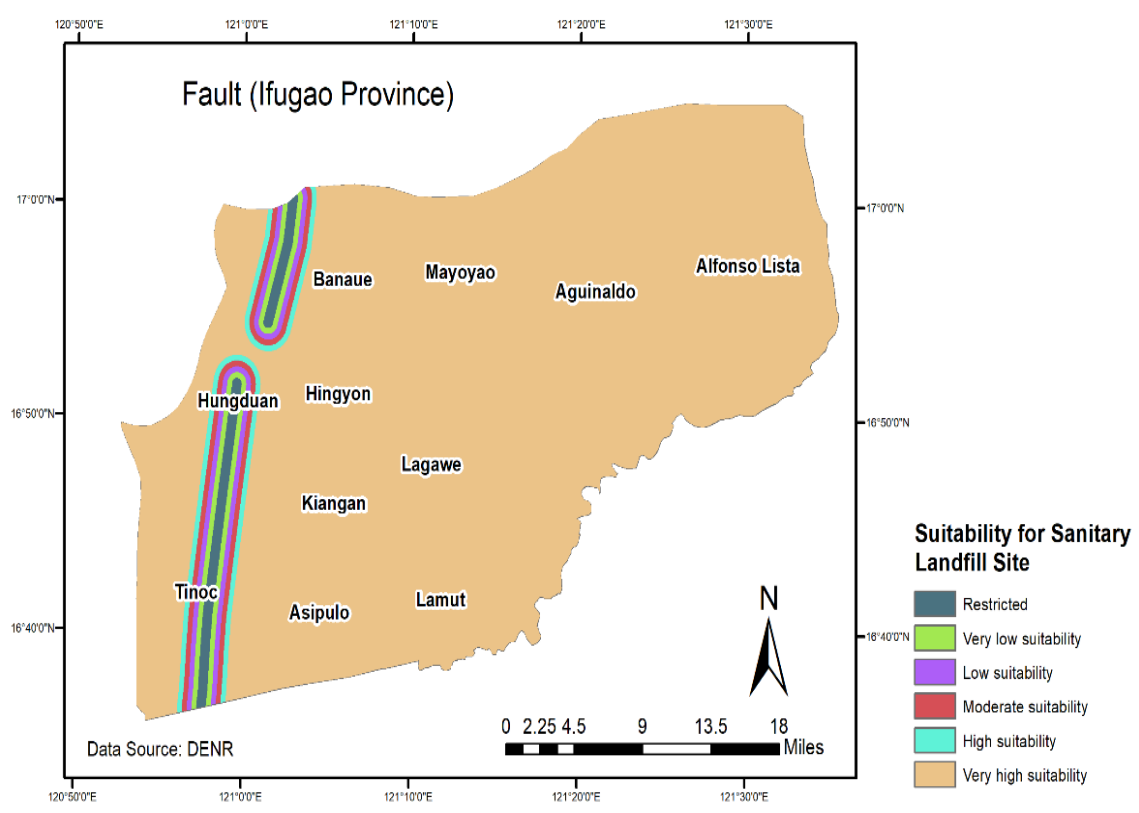

Figure 14. Output map for

Figure 14 shows the resulting map of the faults layer after executing reclassification. Faults layer is under the criterion of Physical and comprises a weight of $10 \%$. Based on the map, a large area in Ifugao province fall on very high suitability for sanitary landfill site using a faults layer.

\section{Conclusion}

The main criteria for the suitability analysis of sanitary landfill sites classified into economic, environmental, and physical. Economic criterion focuses on land use, distance from road, and slope. The environmental criterion determines the suitability of landfill establishment by the assessment of distance from the water surface, groundwaters, distance from environmentally sensitive areas (e.g., distance from key biodiversity areas and protected areas), land cover, soil erosion susceptibility, and soil permeability. Physical criterion uses the distance from settlements, distance from the cultural heritage, and distance from faults (seismic conditions) in the suitability analysis of sanitary landfill establishment. Each criterion and sub-criterion have policy considerations and identified exclusionary zones as needed in the quantification of suitability analysis.

\section{Recommendations}

1) Conduct actual sanitary landfill suitability assessment using the criterion provided in this study. This will identify areas with very highly suitable site/s for the establishment of a sanitary landfill in Ifugao province;

2) Conduct full Environmental Impact Assessment to identify, quantity and predict socio-economic and environmental Impacts. With this, negative impacts can be mitigated, and positive impacts can be enhanced;

3) Comply the requirements and guideline provided by RA 9003 otherwise known as Ecological Solid Wastes Management Act of 2001 in establishing sanitary landfill particularly on: liners, leachate collection and treatment system, gas control recovery system, groundwater monitoring well system, cover, closure procedure and post-closure care procedure

4) Conduct wastes characterization or assessment. Based on wastes characterization/assessment, create policies, incentive-based approach, market other appropriate approach. 


\section{References}

[1] Department of Environment and Natural Resources (1998). Department Administrative Order No. 50 Series of 1998. Adopting the Landfill Site Identification and Screening Criteria For Municipal Solid Waste Disposal Facilities

[2] Kara, C., \&Doratli, N. (2012). Application of GIS/AHP in siting sanitary landfill: A case study in Northern Cyprus. Waste Management and Research, 30(9), 966-980. https://doi.org/10.1177/0734242X12453975

[3] National Solid Wastes Management Council (2015). National Solid Waste Management Commission National Solid Waste Management Status Report (2008-2014). Republic of the Philippines Department of Environment and Natural Resources Environmental Management Bureau.

[4] Retrieved from http://nswmc.emb.gov.ph/wp-content/uploads/2016/06/Solid-Wastefinaldraft-12.29.15.pdf

[5] National Solid Wastes Management Council (2013). Resolution No. 64 series of 2013: Adoption of Modified Guidelines on Site Identification Criteria and Suitability Assessment Procedure for Sanitary Landfill.

[6] Saripalli, N.J. and Sonawane, D.R. (2018). Assessment of Reclaiming Process of Sand as Foundry Waste for Industrial Usage. International Journal of Science and Management Studies (IJSMS) Vol 1 Issue 1, 72-80.

[7] Senate Economic Planning Office (2017). Philippine Solid Wastes, (9003). Senate of the Philippines. Retrieved from https://www.senate.gov.ph/publications/SEPO/AAG_Philippine Solid Wastes_Nov2017.pdf 